KATHOLIEKE UNIVERSITEIT LEVVEN

\section{Faculty of Economics and Applied Economics}

Department of Economics

Regional Competition in the European Union.

by

Filip ABRAHAM

International Economics

Center for Economic Studies

Discussions Paper Series (DPS) 99.07

http://www.econ.kuleuven.be/ces/discussionpapers/default.htm

March 1999

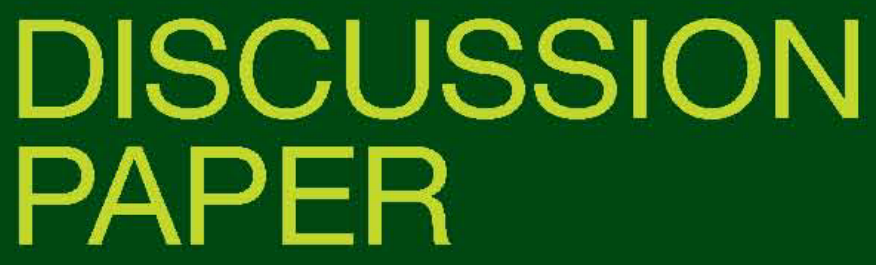




\title{
REGIONAL COMPETITION IN THE EUROPEAN UNION
}

\author{
by
}

\section{Filip Abraham*}

*CES, University of Leuven, Belgium. I am grateful to P. Friedrich and to the participants in the Eleventh Advanced Studies Summer Institute in Regional Science. This research was made possible by NFWO onderzoeks-programma G.0133.96: "Een Lange-Termijn Analyse van het Concurrentievermogen van de Belgische Economie ten opzichte van de Buurlanden, 1900-2000.” 


\section{INTRODUCTION}

In the last decade, regional issues have gradually moved into the centre-stage of the debate on economic integration and international trade in Europe. The fading influence of the nation-state goes together with a transfer of sovereignty to the European level combined with a renewed interest in the region as a relevant economic unit.

Regional authorities are welcoming this evolution as a new opportunity for greater regional autonomy. They are developing political and economic ties with other regions but are at the same time promoting the strategic interests of their own region. This twofold strategy draws a hesitant response from European Union (EU) regulators. They applaud the fact that economic integration strengthens regional complementarities and co-operation. But the increased regional competition raises the prospect of a greater use of policies that distort competition in an integrated economic area. Moreover, EU regional policies that seek convergence between high and low income regions would suffer from a systematic policy of the stronger regions to expand their influence at the expense of the weaker regions.

From a theoretical point of view, those issues raise several questions that are addressed in this paper. What are the driving forces for regional complementarities and regional competition? How does economic integration affect regional competition ? What can "strategic" regional policy do to promote narrowly defined regional interests ? And how do EU-wide policies prevent distortions in regional competition?

This paper addresses those theoretical questions based on the literature in international trade, regional agglomeration and multinational companies. Section 1 starts with a look at theories that predict regional convergence as the outcome of the regional integration process. Section 2 assesses recent theoretical contributions that focus on regional agglomeration and explore the regional consequences of multinational companies. In a third section, the scope for EU policies that prevent destructive regional competition is discussed. 


\section{THE CONVERGENCE APPROACH}

The question whether countries or regions converge as a result of trade integration has been addressed in decades of economic research. International trade economists traditionally adopt the Heckscher-Ohlin-Samuelson (HOS) framework as the basis for their analysis. This model assumes perfect competition in product and factor markets, full employment of all factors, perfect intersectoral factor mobility within countries, identical tastes and access to the same technologies for all countries. This theory leads to a strong convergence result which is most easily understood by the concept of the integrated world equilibrium (see Helpman and Krugman, 1995). In an integrated area, factor and product prices are equalised implying full convergence of income per head.

The driving force of this convergence result depends on the type of model considered. If factors of production are mobile across countries and regions, factor mobility guarantees convergence. Intuitively, this can be grasped by a simple example. If German reunification eliminates all barriers between the western and eastern part of Germany, East German workers will massively move to the west in search for higher wages. West German companies will invest in the East and introduce Western technologies. This process continues until wages and the return to capital are fully equalised in the whole of Germany.

If factors of production do not move across countries (regions), convergence obtains as a result of international (interregional) trade. Countries or regions specialise in products which use intensively the factors of production that are abundant and cheap in that country or region. This explains, for example, the strong trade expansion between selected EU member states with Central and Eastern Europe. As a consequence of those trade relations, the theory predicts that abundant production factors in each country will become more expensive, that countries will adopt the same technology and that income levels will fully converge.

It is clear that reality is more complicated than the theory or the strong convergence result would lead us to believe. Strict empirical tests of the HOS theory are no great success. Trefler (1995) considers a wide sample of 33 countries and 9 production factors using the American input-output technology for every country. He finds that the theory does not perform much better than a toss of the coin. The main culprit for this disappointing result is the assumption that countries use the same technologies. If technological and demand differences are taken into account, the theory does much better. This indicates that 
intersectoral specialisation and convergence factors may interact with technology to determine the world-wide distribution of income levels.

A paper by Davis et al (1997) compares the performance of the HOS theory for a sample of countries and a sample of Japanese regions. They find stronger convergence in income and technology between Japanese regions than between countries. This should not be too surprising because Japanese regions are geographically closer and belong to one country without barriers to trade and factor mobility.

Translating this to the European case, one would expect that convergence is far more likely between regions that have been integrating for a longer period of time. There is indeed evidence that points in this direction. Over time regional inequality is declining in the European Union although this is a slow and discontinuous process (see Abraham and Van Rompuy, 1995). According to Fatas (1997) shocks that are affecting EU regions are becoming more similar over time. Quah (1996) emphasises the importance of regional spillovers between neighbouring EU regions which matter more than macro-economic factors at the national level. He also shows that the convergence in per capita income between neighbouring regions occurs at a faster pace than the average convergence process for all EU regions.

What does all of this imply for regional competition and strategic regional policy ? The main message is that economic integration strengthens the interdependence between regions. This implies that strategic policy by one region will have a strong impact on the surrounding regions. In the extreme case of an integrated equilibrium with perfect factor mobility, economic forces are likely to fully offset the policy. If, for instance, regional policy leads to an increase in per capita income and wage levels, the region will experience an immediate inflow of labour that brings down income and wages to the level of the other regions. In the case of barriers to international factor mobility, a similar outcome is achieved but the process takes much longer through an adjustment in trade and regional specialisation patterns. Even then, the policy may invite countervailing actions by the other regions because they are thoroughly affected by the strong interregional spill-overs. In short, strategic regional policy is ineffective and causes frictions in a world that resembles the HOS framework.

There is a nice corollary to this result. The theory predicts that economic integration promotes regional convergence. Hence, integration achieves the catching-up process that lagging regions often aim at when pursuing a strategic regional policy. Those regions may 
be better off with a policy that promotes regional adjustment and regional integration than seeking higher growth at the expense of other regions.

\section{CONVERGENCE VS DIVERGENCE IN A WORLD WITH REGIONAL AGGLOMERATION AND MULTINATIONAL COMPANIES}

\subsection{Regional agglomeration}

A very different picture of regional adjustment is offered by theories of regional agglomeration. Taking up an old tradition in regional economics, Krugman (1991) elegantly formalises some key driving forces of regional agglomeration. Krugman's theoretical assumptions deviate in several essential ways from the HOS trade model. He introduces imperfect competition in product markets by assuming an imperfectly competitive sector with product differentiation, monopolistic competition and Dixit-Stiglitz preferences. Manufacturing wages across regions are not necessarily equalised as a result of regional integration. Companies and manufacturing labour are mobile between regions but the perfectly competitive agricultural sector is characterised by immobile farms and farmers. Free entry of manufacturing companies guarantees zero profits in the long run.

In Krugman's model, equilibria with regional convergence and regional divergence are both possible. Regional wage differentials foster regional convergence of income levels. Lower wages offer an incentive for companies in high wage regions to relocate. In this way, the regional wage gap is gradually closed. This convergence process is however counteracted by mechanisms that lead to regional divergence in income levels. Proximity to a large market with high income levels attracts companies to locate in richer regions. In those markets, firms are able to exploit economies of scale which lower their average costs and strengthen their competitive position. In Krugman's model, economies of scale are directly linked to market power. Stronger economies of scale lead to more market power and less competition. Ceteris paribus, firms prefer to be present in markets with a lower degree of competition and fewer competitors.

Regional divergence follows from a cumulative process of self-reinforcing agglomeration. Figure 1 presents this process in a simplified way. Assume that, for some exogenous reason, demand in a region increases. Local companies benefit from this expansion of demand by exploiting economies of scale which increases profitability. The enhanced profitability 
attracts new firms to the region. The increased competition and the lower average costs translate in lower product prices : Krugman labels this as the competition effect. In turn, lower prices raise the aggregate spending power of consumers through the effect on the aggregate price index. New manufacturing jobs are created and labour moves in from other regions attracted by high incomes and favourable employment perspectives. Increased purchasing power and more consumers raise demand and set in motion a new round of regional expansion.

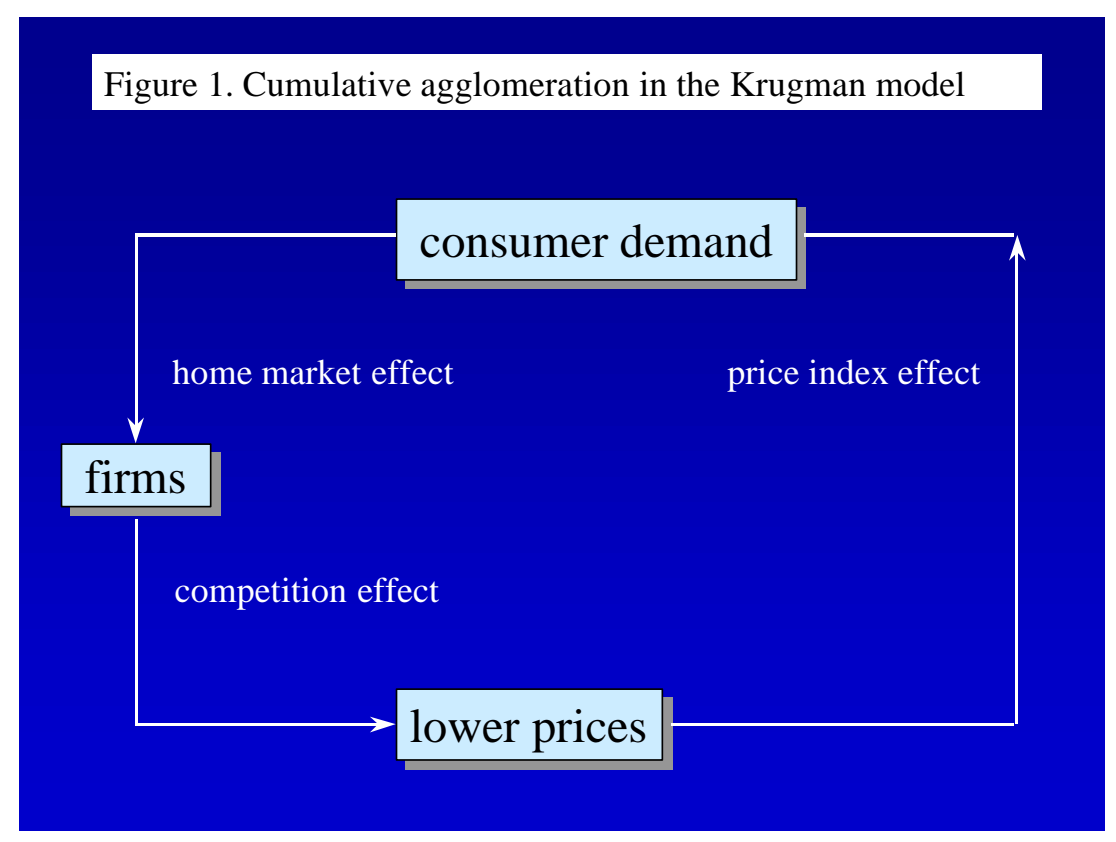

The stylised Krugman model has been extended in later work to incorporate intermediate inputs. Innovation and capital investment provide other sources of regional agglomeration. Figure 2 shows how those driving forces interact with the determinants of the Krugman model. This diagram makes an explicit distinction between final goods producers and intermediate input suppliers.

The right hand side of the diagram reproduces the Krugman set-up with the difference that competition between final good producers may induce cost-reducing innovation and may lead to additional price cuts in the long run. The left hand side of the diagram focuses on the interdependence between final and intermediate input producers. Higher demand for final goods spills over in additional intermediate demand and engenders a home market effect for companies supplying intermediate products. Economies of scale, innovation and competition bring down the price of those inputs which in turn allow final good producers to charge lower prices. A self-reinforcing process of rising regional income levels, 
innovation and clustering of companies and their suppliers takes place. The prospering region leaps ahead in front of the other regions.

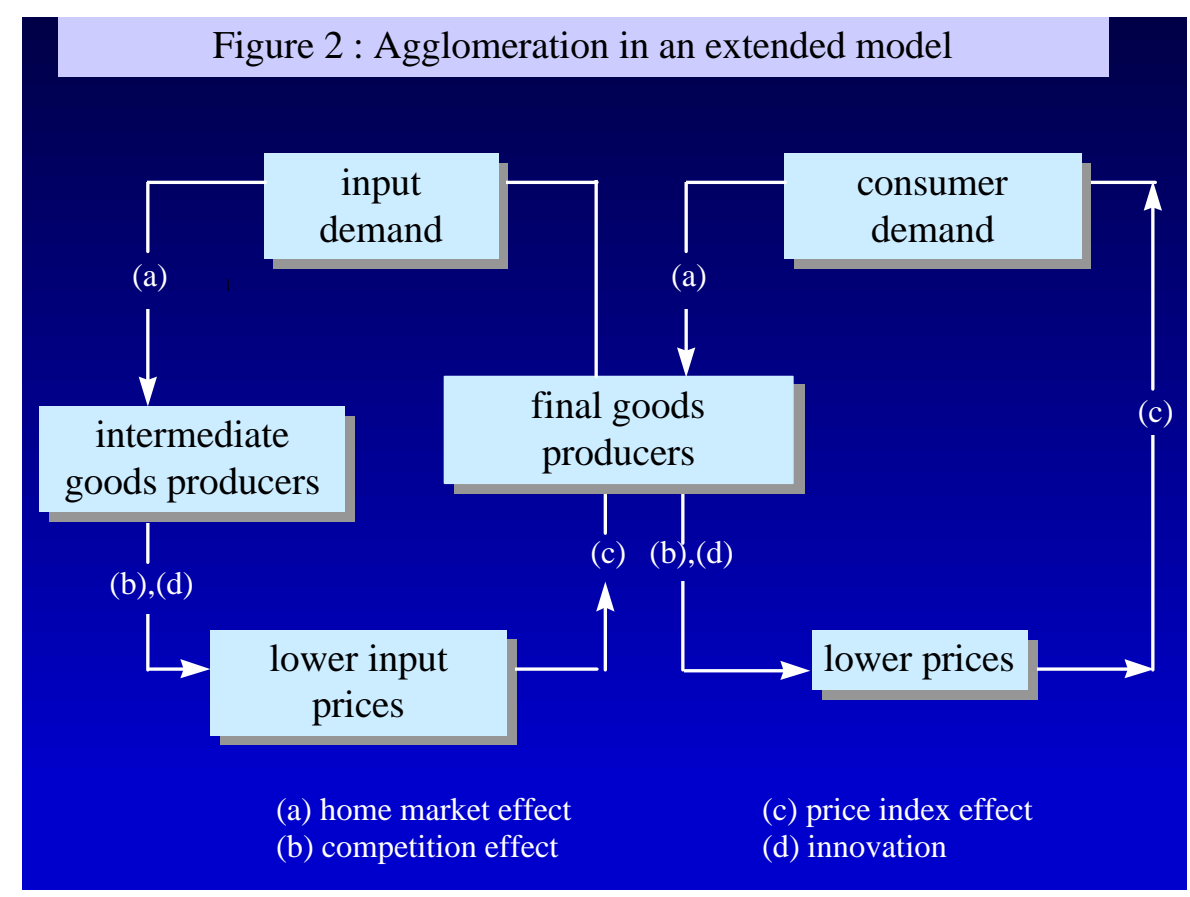

Evidently, this process cannot go on forever. Krugman links the scope for regional divergence to - among other factors - trade barriers and transport costs. Interestingly, in a fully integrated area without such impediments the model reproduces the income convergence result that characterises the HOS approach. In such setting any divergence in regional wage levels encourages companies to exploit lower wage costs in the lagging region and to ship the products at no cost to the larger market in the high income region. On the contrary, partial economic integration may actually strengthen regional divergence instead of promoting convergence as it does in the HOS framework. The reason is that trade and other impediments shield companies in smaller regions from exports of firms from other regions. When this protection is removed, stronger competition gives those companies an incentive to locate closer to the larger market and serve the lower income region by exporting rather than by local production. If so, the income gap between the richer and the lagging region widens as a consequence of economic integration. 


\subsection{Regional integration and multinational strategies}

In the Krugman approach firms can move but they locate in one region only. In reality, the growth of multinational companies with operations in many countries has been spectacular in the last decades and exceeds the expansion of international trade volumes. A longstanding research tradition attributes the motivation for multinational activities to company-, plant- and location-specific advantages (see for instance Dunning,1980). More recently, work by Brainard (1997) and Markusen et al. (1996),among others, links those ideas to the newer theoretical developments in international trade and regional agglomeration. Which insights do we obtain about regional convergence versus regional divergence ?

To address this question, it is useful to compare the theoretical set-up with the standard Krugman approach. In fact, the building blocks are very similar with the exception that the models with multinational companies make a distinction between company-specific economies of scale such as headquarter services, corporate management or innovation breakthroughs and plant-specific scale economies arising primarily from cost reductions due to longer production runs. When the latter type of scale economies dominates, companies have a tendency to concentrate production in one or a few plants and adopt an export strategy. When economies of scale are primarily achieved at the corporate level, it pays off to produce in several countries or regions. In this case, we observe plants producing similar products in many locations (regions or countries) which we denote as horizontal strategies. Alternatively, companies may want to exploit international or interregional cost differences by establishing manufacturing plants with lower value added in low wage regions and by concentrating headquarters and $R \& D$ in areas with a highly educated labour force. We define this approach as a vertical strategy. Empirical evidence indicates that both vertical and horizontal strategies are observed but that horizontal strategies are more common (e.g. Abraham and Konings, 1997).

The distinction between horizontal and vertical strategies is important for the debate on regional complementarities and regional competition. Horizontal strategies are motivated by the desire to be present in large and growing markets. Production is primarily targeted at the regional market where the plant is located and not at exports to the home market of the multinational company. As a consequence, competition between different plants of the same company is not so common while complementarities at the corporate level often exist through the provision of specialised inputs, $\mathrm{R} \& \mathrm{D}$, headquarter and management services. By contrast, vertical strategies usually put regions or countries in direct competition when multinational firms select the location with the best combination of cost conditions and 
productivity levels. In this situation regional and national authorities have a powerful incentive to attract companies by providing favourable investment conditions.

What is the relation between economic integration and regional convergence in models of multinational operations ? Vertical strategies exploit cross-border factor price differentials and, in this way, promote the convergence between higher and lower cost regions. However, some production activities are likely to be closed down in the higher cost region. This delocalisation creates political and social resistance against the convergence process. Another finding of the theoretical literature is that convergence in regional income levels makes horizontal strategies more likely. This would imply that regional complementarities dominate in regions with similar income levels while regional competition is the most pronounced when integration is considered between regions at different stages of economic development.

\subsection{Strategic regional policy}

As became clear in the preceding paragraphs, the introduction of agglomeration effects and multinational strategies in trade models offers insights that are not captured by the HOS approach. In effect, we obtain a broader picture of the determinants of regional competitiveness. Relative factor endowments - which are the basis for regional specialisation in HOS models with imperfect factor mobility - remain an important factor. But a regional competitive advantage can also be built on (i) the presence of a large and growing market (ii) innovation and efficient technologies (iii) economies of scale and learning effects and (iv) vertical links between companies.

This broader view widens the scope for strategic regional policies. Policies that strengthen the productive base of a region and that raise the productivity of the regional labour force and the regional capital stock contribute to regional competitiveness. Innovation policy and subsidies to $R \& D$ may promote regional innovation. Regions can attract business by providing tax breaks and subsidies to selected companies in strategic sectors. Or they may attempt to control the evolution of wages and non-wage labour costs to make their region an attractive low cost area to invest.

Those strategic policies are not without risk for reasons mentioned earlier. It remains true that interregional dependence creates direct spill-overs from one region's strategic policy to competing regions. This invites countervailing actions by other regions and may trigger a 
full-fledged regional subsidy war which harms all regions. The literature on strategic trade policy (see Eaton and Grossman, 1986) emphasises that such outcome is the logical consequence of the greater scope for strategic policies. In fact, regions are confronted with a standard prisoner dilemma : while they would benefit from an overall ban on strategic policies, the incentive for each individual region to engage in such policies is too strong. To avoid this negative scenario, a binding commitment is needed that refrains regions from doing so. In the European context, the responsibility for preventing a race-to-the-bottom that is a mutually detrimental competition among regions and countries - is placed in the hands of EU institutions.

\section{EU POLICY TOWARDS REGIONAL COMPETITION}

A broad range of EU policies explicitly or implicitly aim to avoid a race-to-the-bottom. As seen in Table 1, regional policy, fiscal harmonisation and social policy can be viewed from this perspective. For each of those policy fields, the table distinguishes between three regulatory strategies. Policy can be aimed at establishing EU minimum standards which keep countries or regions from triggering a downward spiral. Alternatively, EU policy initiatives can promote regional adjustment, co-ordination and agreements between regions, countries and interest groups. This strengthens mutually beneficial complementarities. Finally, sanctions can be used in the framework of EU competition policy.

EU regional policy counteracts a race-to-the-bottom in an indirect way. The objective is to promote regional cohesion within the EU by closing the gap between the higher and lower income regions. In doing so, lagging regions have fewer incentives to conduct policies that attract business at the expense of other regions. Moreover, the centralisation of regional subsidisation at the European level should allow for a more objective assessment of the regions that are in need of structural assistance. EU regional policy takes a regulatory approach of establishing minimum targets for relative income per capita of European regions. Most of the regional funds go to Objective 1 regions which have a GDP per capita that does not exceed $75 \%$ of the EU average. 
Table 1 : EU policy towards regional competition

\begin{tabular}{|c|c|c|c|}
\hline $\begin{array}{l}\text { EU regu- } \\
\text { latory } \\
\text { approach }\end{array}$ & $\begin{array}{l}\text { Regional } \\
\text { policy }\end{array}$ & $\begin{array}{l}\text { Fiscal } \\
\text { harmoni - } \\
\text { sation }\end{array}$ & $\begin{array}{l}\text { Social } \\
\text { policy }\end{array}$ \\
\hline $\begin{array}{l}\text { minimum } \\
\text { require- } \\
\text { ments }\end{array}$ & $\begin{array}{l}\text { achieve } \\
\text { minimum } \\
\text { regional } \\
\text { GDP per } \\
\text { capita }\end{array}$ & $\begin{array}{l}\text { - establish } \\
\text { minimum } \\
\text { tax rates } \\
\text { - VA T } \\
\text { - financial } \\
\text { taxes } \\
\text { - profit taxes }\end{array}$ & $\begin{array}{l}\text { - establish } \\
\text { minimum } \\
\text { social } \\
\text { protection } \\
\text { - social } \\
\text { chapter } \\
\text { Maastricht }\end{array}$ \\
\hline $\begin{array}{l}\text { promote } \\
\text { coordina- } \\
\text { tion, } \\
\text { adjust- } \\
\text { ment and } \\
\text { agree- } \\
\text { ments } \\
\end{array}$ & $\begin{array}{l}\text { - EU } \\
\text { regional } \\
\text { funds } \\
\text { - additiona- } \\
\text { lity } \\
\text { - evaluation }\end{array}$ & $\begin{array}{l}\text { - code of } \\
\text { conduct }\end{array}$ & $\begin{array}{l}\text { - EU social } \\
\text { funds } \\
\text { - target } \\
\text { approach } \\
\text { - EU social } \\
\text { agree- } \\
\text { ments }\end{array}$ \\
\hline - sanctions & $\begin{array}{l}\text { no more } \\
\text { regional } \\
\text { transfers }\end{array}$ & $\begin{array}{l}\text { - competi- } \\
\text { tion policy } \\
\text { on } \\
\text { subsidies }\end{array}$ & $\begin{array}{l}\text { - competi- } \\
\text { tion policy } \\
\text { on } \\
\text { subsidies }\end{array}$ \\
\hline
\end{tabular}

Regional funds promote regional adjustment by improving the structural conditions in lagging regions. A sustained willingness to pay by the prosperous regions requires that the money is spent wisely. The principle of additionality, according to which the receiving countries are obliged to finance part of the regional projects, is supposed to contribute to a selection of viable projects. At the end of the project an evaluation of the effectiveness of the regional programs is carried out by the EU Commission. As a sanction, future regional funding can be cut if program objectives are not met. In spite of those efforts, the efficiency of regional support remains a controversial issue.

With the creation of a monetary union, fiscal harmonisation is quickly becoming one of the top priorities on the EU policy agenda. In an integrated economic zone with a single currency, differences in VAT, corporate taxation and financial taxes exert a profound impact on capital flows and on the location of companies. The concern prevails that countries will compete in attracting companies and financial investment by offering a favorable tax treatment. This would easily trigger a sharp EU-wide reduction in taxation of mobile production factors. Confronted with declining tax revenues, governments may have to cut expenditures on essential public functions or to raise taxes on the less mobile production factors. Already, there is evidence of a gradual shift in taxation from capital to labour in most EU countries since the early 1980's. Higher labour taxes, in turn, contribute to rising labour costs which push up unemployment. 
To a large extent, the EU approach towards taxation is based on the concept of minimum tax rates and increased transparancy in areas that are most sensitive to competitive distortions. Those efforts led to the adoption of EU-wide minimum VAT and excise tax rates in the early 1990's. So far, no consensus has been reached on minimum financial and profit taxes although European monetary union is reviving the interest for a comprehensive tax agreement. Nevertheless, fiscal harmonisation requires unanimity in the EU Council of Ministers. In view of the opposition against EU tax initiatives by member countries such as Luxembourg and the UK, unanimity is not easily achieved.

In December 1997, agreement was reached by EU member states on the so-called Code of Conduct. This code deals with corporate taxation and provides an interesting example of how member countries can mutually co-ordinate their tax policies on a European scale. EU member countries pledged to abolish special tax schemes that grant substantial tax advantages to selected companies. In this way, the agreement deviates from the usual EU ambition to determine legally binding minimum tax rates through direct EU legislation.

EU competition policy dealing with national subsidies (Article 92-93 of the Treaty of Rome) gives the European Commission the authority to act against subsidies that distort competition on EU markets. When regions grant and companies or industries obtain subsidies or tax advantages, the Commission can order national and regional authorities to abolish the subsidy or tax scheme. The companies can be obliged to repay the subsidy. This sanction-based approach allows for a case-by-case treatment of distortive measures but does not involve the creation of a broader legislative framework that sets the ground rules for fiscal competition in the EU.

The goals of EU social policy are to stimulate employment and to guarantee a sufficient degree of social protection. The relevance for this paper stems from the argument that EU social policy may help to prevent a downward spiral in social protection. While there is little evidence that full-fledged social dumping is actually taking place, intensive competitive pressure in an integrated European market gives countries or regions an incentive to lower social protection in an effort to reduce labour costs.

EU social policy involves the three regulatory strategies that were discussed above. According to the Social Protocol to the Maastricht Treaty, the EU is assigned the competence to establish legally binding minimum requirements in selected social domains with a qualified majority in the Council of Ministers. This had led to a few directives dealing 
with maternity leave, working time and the information of workers in larger companies. So far, the scope of this social legislation is rather limited not in the least because social security is largely left untouched.

Furthermore, the Social Protocol to the Maastricht Treaty encourages social agreements between employers and unions on a European scale. If such an agreement is reached on a specific issue, EU institutions will refrain from own legislative initiatives in this domain. Up to now, EU-wide social agreements cover parental leave for smaller children and the rights of part-time workers and of other employees with an a-typical working time. The failure to reach a consensus between unions and employers on work councils and worker information in smaller companies is prompting the European Commission to advance its own legislative proposals.

EU institutions also play a role in co-ordinating joint social initiatives of member countries. A recent example is the target approach for unemployment that was launched at the end of 1997. In the European Council, member countries agreed on quantitative targets for the training and the reintegration of unemployed workers in the labour force. Countries were free to make their own proposals on how to achieve those targets. Subsequently, the proposed plans were evaluated by the EU Commission. Presumably this target approach could also be used to avoid a race-to-the-bottom in social protection. This strategy can be backed up by EU competition policy on national subsidisation. In fact, the European Commission is opposed to selective reductions in social security contributions granted to specific companies, sectors or regions.

\section{CONCLUSION}

This paper takes a broad view on regional competition in the EU. Against the background of the recent literature in international trade, regional agglomeration and multinational strategies, we focus on the driving forces of regional competition. We point to the scope for and the risks of strategic regional policies and assess what EU authorities are doing to prevent a detrimental escalation of beggar-thy-neighbour policies.

An eclectic view on the theories surveyed in this paper leads us to conclude that there are many determinants of regional competitiveness. Regions can try to develop regional strengths by adopting appropriate policy initiatives. Those regional policies do not necessarily come at the expense of other regions. Many complementarities exist among 
European regions and those can be strengthened by ambitious projects of market integration, regional adjustment and convergence between higher and lower income regions. By contrast, regional integration can also intensify strategic competition among regions. This is particularly the case in a setting with competing regional clusters and multinational companies that base their investments on a detailed comparison of regional productivity and cost levels. In this environment regions have a strong incentive to lure business away from competing regions by subsidies, tax breaks, reduced labour costs and lower levels of social protection.

Strategic policies are not without risks in an integrated economic area. They are ineffective when factor mobility and trade in goods and services quickly neutralise regional imbalances in income and wage levels. They are counterproductive when they draw a countervailing policy response from competing regions or countries. They are outright harmful when countries or regions get involved in a subsidy war, a race-to-the-bottom in social standards or a sharp reduction in tax revenues.

EU policies help to prevent this negative outcome. In this paper, we highlighted the role of EU regional, tax and social policies in establishing minimum requirements and in promoting co-ordination and consensus. We mentioned that EU competition policy on national subsidies can be used to act against competitive distortions caused by policy measures of national or regional governments.

Does the existing EU policy framework guard against mutually destructive competition between regions and countries? The answer to this question is not straightforward because it is unclear whether the race-to-the-bottom scenario indeed poses a real threat at this stage. Neither are we able to fully assess the incentives for regional competition in the changing environment of a monetary union. What can be said however with reasonable confidence is that the current EU regulatory framework is too fragmentary to prevent widespread beggarthy-neighbour policies if countries or regions would decide to take this route. But then again, regions or countries may very well refrain from doing so when they become aware of the risks of strategic policies. They may instead prefer a more comprehensive set of EU rules that strengthen mutually beneficial co-operation. 


\section{REFERENCES}

Abraham, F. and J. Konings (1997) "Does the Opening of Central and Eastern Europe Threaten Employment in the West ?" Forthcoming in The World Economy.

Abraham, F and P. Van Rompuy (1995) " Regional Convergence in the European Monetary Union," Papers in Regional Science, vol 74(2), p 125-142.

Brainard, S.L. (1997), "An Empirical Assessment of the Proximity-Concentration Trade-off Between Multinational Sales and Trade", American Economic Review, vol. 87, no. 4, p. 520-544.

Davis, D.R., Weinstein, D.E., Bradford, S.C. and K. Shimpo (1997), "Using International and Japanese Regional Data to Determine When the Factor Abundance Theory of Trade Works", American Economic Review, vol 87 no 3, p 421-446.

Dunning, J.H. (1980) “Towards an Eclectic Theory of International Production: Some Empirical Evidence,” Journal of International Business Studies, vol 11, p 9.

Eaton, J. and R. Grossman (1986), "Optimal Trade and Industrial Policy under Oligopoly”, Quarterly Journal of Economics, 386-406.

Fatas, A. (1997), "EMU: Countries or Regions? Lessons from the EMS Experience," European Economic Review, vol 41 no 3-5, p 743-752.

Helpman, E. and P. Krugman (1985), Market Structure and Foreign Trade. Increasing Returns, Imperfect Competition, and the International Economy. MIT Press, Cambridge.

Krugman, P. (1991), "Increasing returns and economic geography", Journal of Political Economy, Vol. 99, no. 3, p 483-499.

Markusen, J.R., Venables, A.J., Konan, D.E. and K.H. Zhang (1996), “A unified treatment of horizontal direct investment, vertical direct investment and the pattern of trade in goods and services", NBER Working Paper no. 5696.

Quah, D. (1996), "Regional Convergence Clusters Across Europe," CEPR Discussion Paper no 1286.

Trefler, D. (1995), “The Case of the Missing Trade and Other Mysteries. The American Economic Review, 85, no. 5, 1029-1046. 
